\title{
Intellectual Capital: An Exploratory Study from Lebanon
}

\author{
Hussin J. Hejase ${ }^{1 *}$, Ale J. Hejase ${ }^{2}$, Hassana Tabsh ${ }^{3}$, Hassan C. Chalak ${ }^{4}$ \\ ${ }^{1}$ Faculty of Business Administration, Al Maaref University, Beirut, Lebanon \\ ${ }^{2}$ Faculty of Economics and Business Administration, Islamic University of Lebanon, Beirut, Lebanon \\ ${ }^{3}$ Human Resources Office, Lebanese American University, Beirut, Lebanon \\ ${ }^{4}$ Faculty of Business and Economics, American University of Science and Technology, Beirut, Lebanon

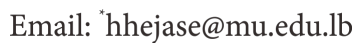

How to cite this paper: Hejase, H.J., Hejase, A.J., Tabsh, H. and Chalak, H.C. (2016) Intellectual Capital: An Exploratory Study from Lebanon. Open Journal of Business and Management, 4, 571-605.

http://dx.doi.org/10.4236/ojbm.2016.44061

Received: July 12, 2016

Accepted: August 19, 2016

Published: August 22, 2016

Copyright $\odot 2016$ by authors and Scientific Research Publishing Inc. This work is licensed under the Creative Commons Attribution International License (CC BY 4.0).

http://creativecommons.org/licenses/by/4.0/ (c) (i) Open Access

\begin{abstract}
Organizations are spending quality time to build their Intellectual Capital by attracting people with talent; a caliber that has become a valuable asset in the business world, especially since talented people are difficult to find. Intellectual Capital is the knowledge that individuals put into advantage in their respective companies; as such, it is an organizational competitive advantage and helps in value creation. The Human Resources Department creates value for these organizations by coming up with effective humanresource related solutions and creative ideas for dealing with and retaining people who have the right talent. To achieve the aforementioned, employees' qualifications have to be evaluated in terms of knowledge, skills, education, in addition to future potentials and ability to cope with change. Consequently, organizations have become interested in developing their human capital by developing their employees' knowledge, applied experience, enterprise process, customer relationships, and professional skills. This paper discusses "Intellectual Capital" as a modern HR concept that has influenced business processes and plans. It aims at exploring and assessing the extent of awareness of such concept, current challenges it faces, its future, and also the different views and thoughts regarding it. In addition, the research focuses on how to exploit and retain Intellectual Capital and identifies the financial and non-financial organizational benefits gained by employees. The research is exploratory and explanatory, quantitative in nature using a survey questionnaire responded by 258 Lebanese employees and managers working in different business sectors. Collected data are evaluated statistically through computer software SPSS-22. Findings are used to support existing managerial practices and policies for better retention practices and management of Lebanese human resources.
\end{abstract}

\section{Keywords}

Human Capital, HR, Intellectual Capital, Lebanon, Retention, Talent 


\section{Introduction}

Intellectual Capital is currently a popular and extensively discussed topic. According to Huang and Liu (2005), there is a widespread recognition that Intellectual Capital is a critical force that drives economic growth [1]. In the past, enterprises were solely considered and evaluated by their physical and tangible assets, whereas now, the details of their financial or nonfinancial assets are fundamental factors in the evaluation process whereby a much accurate consideration of firms' real value is required; this shift is a leading reason as to why Intellectual Capital has incurred a critical value for companies and nations. Lockwood (2005; cited in [2]) contends that in "today's global marketplace, talent management represents one of the greatest challenges for HR leaders: successful talent management requires effective alignment of human capital and business strategies to support organizational financial goals and positively impact shareholder value" (p. 1). Rappaport (2006) asserts that "companies can develop leading indicators of value, which are quantifiable, easily communicated current accomplishments that frontline employees can influence directly and that significantly affect the long-term value of the business in a positive way" [3] (Para 29).

There are several objectives that have led the researchers to choose this major topic. First of all, this research will let readers and researchers understand what Intellectual Capital is. Readers will understand how this capital contributes to the organizations' success. Managers and businessmen will be able to assess its true value to organizations, and will know how to utilize the most valuable asset, the people, to tap into the deepest power within the organization. This paper will also show the importance of exploring employees' skills and needs. It will majorly determine how Intellectual Capital is managed to enhance its potential to increase wealth. Organizations may be unaware of the extent and importance of their Intellectual Capital for future sustainability; accordingly, this research is designed to highlight the importance of this capital. The research explores how Intellectual Capital is perceived by an organization and how it is being managed.

\section{Literature Review}

Robbins and Coulter (2009) contend that, "management involves coordinating and overseeing the work activities of others so that their activities are completed efficiently and effectively" [4] (p. 22). However, the implied meaning in this definition needs to be well clarified so as to understand its relation to Intellectual Capital. Robbins and Coulter (2009) assert that first of all, an organization is "a deliberate arrangement of people gathered to accomplish some specific purpose" [4] (p. 30). Hence, any organization, whether new or old, small or big, requires certain methods, procedures and plans in place for its efficient functioning. For this to happen, these organizations must develop and implement management concepts which help them implement their vision for the future of the organization. Each organization has a distinct purpose. Therefore, as people within the organization have become of central importance to an organization, and since the human resource function is the guardian of talent within the organiza- 
tion, it becomes imperative to address Human Resources management (HRM). Lockwood (2006), in a study for the Society for Human Resource Management - SHRM, encourages companies to seriously invest in human capital, whereby "HR leaders act as business partners while working closely with senior management to attract, hire, develop and retain talent" [5] (Para 1). Mondy and Mondy (2012) define Human Resources Management (HRM) as "the utilization of individuals to achieve organizational objectives. Consequently, managers at every level must concern themselves with HRM. Basically, all managers get things done through the efforts of others; this requires effective HRM. Individuals dealing with human resources matters face a multitude of challenges, ranging from a constantly changing workforce to ever-present government regulations, a technological revolution, and natural disasters as flooding, hurricanes, and tornadoes. Furthermore, global competition has forced both large and small organizations to be more conscious of costs and productivity. Because of the critical nature of human resources issues, these matters must receive major attention from upper management" [6] (p. 30).

Consequently, and based on the aforementioned interest in human resources, it is imperative for the organization to maintain a productive working environment, build positive interpersonal relationships and engage in problem solving. This can only be done effectively, with proper communication among employees. "Communication can help motivate, build trust, create shared identity and spur engagement; it provides a way for individuals to express emotions, share hopes and ambitions and celebrate and remember accomplishments. Communication is the basis for individuals and groups to make sense of their organization, what it is and what it means" [7] (Para 9).

HR practices have undergone many changes since 1950s. Jayaraman (2012) found that "driven by continuous changes in the business conditions accompanied by aggressive advancements in technology, people practices have helped in significant improvements in productivity and value creation" [8] (p. 14). In response to the aforementioned changes it became apparent that total people's engagement and involvement at all levels of the organization is a must or a necessity. Hence, to generate organizational wealth and to secure sustainability, the HR function had to encourage people to collaborate, to align behind the vision and mission of the organization, to follow a well-established strategy, and to meet the needs and aspirations of customers [8].

Conner and Ulrich (1996) claim that it is imperative for the HR function to undergo a large-scale transformation, and that many companies are discovering the need to reinvent the Human Resource function [9] (p. 38). Nonetheless, Lawler III (2011) declares that the "HR function has not progressed significantly in terms of its strategic role in corporations" [10] (p. 171); "Fundamental change is needed in how organizations are designed to make and implement decisions concerning Human Capital" [10] (p. 172).

Companies have the choice to either respond to change or to lead the change. Consequently, HR executives need to approach the opportunity to shape how they respond to the demands that their function entails; otherwise, HR executives who stick with the status quo and maintain a focus on transactional work will soon become obsolete. 
Moreover, HR professionals who meet the need for strategic expertise concerning human capital management and organizational effectiveness will contribute value that far exceeds the past contributions of the HR function. In the process, HR professionals will make themselves indispensable to their organizations [11].

According to Adelman (2010) [12], a key challenge today is that employees have excellent "Tacit Knowledge", that is, knowledge about their job, the business processes, the data that supports their job and those processes, as well as knowledge of how to most effectively make things happen, and the insight into what works and what does not. Unfortunately, in most situations, the said employees have no means, or incentive to share their knowledge. Their tacit knowledge has not been captured, transferred, or made available to others. "One impact of today's recession and unemployment situation is that this knowledge is potentially lost to the organization. HR professionals and managers have a major challenge to obtain and store information about: 1) core job knowledge of all employees, their experience, and their key skill-sets; 2) training; 3) performance review systems and measurement metrics; 4) development of effective succession planning systems; and 5) leadership and management development programs" [12] (Para 10).

Herein are some excerpts of how Intellectual Capital has been defined in literature.

\subsection{Intellectual Capital}

Many prominent authors have presented a general concept of Intellectual Capital (IC) ([13], [14]). The term "Intellectual Capital" was first introduced by John Kenneth Galbraith in 1969 [15] (p. 1337). Kozak (2011) pointed out that the concept of Intellectual Capital is still underdeveloped, and there is no uniform definition accepted for identifying its subcomponents [16]. However, many researchers have attempted, in various ways and for over a few decades, to define the concept of Intellectual Capital.

"Intellectual capital has been considered by many, defined by some, understood by a select few, and formally valued by practically no one" (Sveiby, 1997; cited in [17], p. 298). Intellectual Capital has been rarely understood or studied. For organizations; Intellectual Capital is considered as an essential source to gain competitive advantage [18]. IC is described by Edvinsson and Sullivan (1996, p. 358) as the knowledge assets that can be converted into value [19]; knowledge that Stewart (1997) contends has been given by individuals to the company, which is supposed to be an organizational competitive advantage and helps in value creation [20]. Moreover, Edvinsson (1997; cited in [21]) emphasizes that "Intellectual Capital includes all the processes and the assets which are not normally shown on the balance sheet and all the intangible assets (trademarks, patents and brands) which modern accounting methods consider" [21] (p. 82). It includes the sum of the knowledge of its members and the practical translation of their knowledge. Intellectual Capital is the difference between the book value of the firm and the amount of money someone is prepared to pay for it [22].

In Edvinsson's (1997) view, Intellectual Capital is a combination of Human Capital (the brains, skills, insights and potential of those in an organization) and Structural 
Capital (things like the processes wrapped up in customers, processes, databases, brands and systems). Intellectual Capital is the ability to transform knowledge and intangible assets into wealth-creating resources, by multiplying human capital with structural capital. This is the Intellectual Capital multiplier effect [23].

Harrison and Sullivan (2000) [24] state that Intellectual Capital is knowledge that can be converted into profit. "Intellectual Capital" represents the main firm intangible resource that can help create opportunities for stable competitive advantage and also help create value and wealth in a Knowledge-based Economy ([25], [26]).

Stralser (2004) states that "Intellectual Capital consists of the knowledge, expertise, and dedication of an organization's workforce. The management of Intellectual Capital is necessary in order to get the most out of an organization's material resources and achieve organizational goals" [27] (p. 19). Getting the most from employees necessitates appropriate motivational policies, for "motivation is an important driver in an organization and is crucial to the management of Intellectual Capital" [27] (p. 20). Moreover, effective and efficient utilization of Intellectual Capital constitute a primary goal of high-performance organizations. Stralser (2004) contends that "high-performance organizations focus on Employee Involvement, Teamwork, Organizational Learning, Total Quality Management (TQM), and Integrated Production Techniques" [27] (p. 33).

Intellectual Capital, in the last two decades, has been defined as a valuable intangible resource, which positively affects the firm's economic value [28], firm's performance [29], and firm's value depicted by the difference between the market value and booked organization assets [26]. The aforementioned term "Intangible" is a concept on whose definition no consensus exists. Authors like Lev (2001) [22], Andriessen (2004) [30], and Cohen (2005) [31], argue about the intangibles' impact on businesses and on company's value creation; thus, historically, intangibles have been treated as an aggregated amount (goodwill), without impact on national wealth, neither is included in financial statements of firms. According to Lev (2001), an intangible asset is any asset that has a future economic benefit or income for the organization but does not have physical representation, such as goodwill [22]. It could be considered as an accounting element. Blair and Wallman (2003) define "Intangibles as non-physical factors that contribute to, or are used in, the production of goods or the provision of services or that are expected to generate future productive benefits to the individuals or firms that control their use" [32] (p. 451). While Andriessen (2004) considers that intangible assets should rather be regarded as intangible resources, because the asset term implies control and ownership, while resource is more appropriate to the intangible nature [30]. As for Epstein and Mirza (2005), "goodwill, in nature, represents a residual, which incorporates all intangibles that cannot be measured separately. The researchers focus on those ones that can be identifiable and be measured under impairment approaches, having or not an indefinite lifetime" [33] (p. 234).

\subsection{Knowledge and Intellectual Capital}

In their definition, Carroll and Tansey (2000) state that Intellectual Capital is best con- 
ceived as the knowledge and creativity available to a firm to implement a business strategy that maximizes stakeholders' value [34]. The definition is broad and designed in such a way that it refers to the benefits to be gained through the application of knowledge. Moreover, the importance of Intellectual Capital has seriously increased in the recent years, since the gap between market values and book values of firms is getting wider; "Especially between the late 1990s and early 2000s, firms with intangible assets enlarged tremendously. A large portion of the value of these firms was linked to their intangible assets instead of tangible and physical assets" [35] (p. 328). Furthermore, Seetharaman, Sooria, and Saravanan (2002) contend that in the new economy, knowledge is considered to be a vital production factor and is the most important competitive advantage of organizations [36]. Later on, Rastogi (2002) asserts that the Intellectual Capital of an enterprise represents its holistic capacity and prowess to create value through exploitation of knowledge as the quintessential resource [37]; a fact supported by Foray (2004; cited in [38], p. 15) who points out that in the knowledge-based economy, the contribution of intangible assets is greater than tangible assets. Also, as Peter Schwartz wrote in the September 2000 issue of "Red Herring" (cited in [39]) that "in the organization of today's economy, it is knowledge that counts more than anything, knowledge has value. Creating value is about creating new knowledge and capturing its value. The most important property is Intellectual Property. Committed employees creating new ideas, delivering value, and innovating to create growth are the key assets of the new economy" [39] (p. 2). Also, with the revolution in information technology, in the early 1990s, the global economy model has changed fundamentally. In today's knowledge economy, knowledge is the most important capital and has replaced financial and physical capital [40]. Moreover, Mitchell (2010) asserts that to every business that exists to increase wealth, Intellectual Capital is critical to achieve greater wealth and results [41]. And finally, Pourkiani, Sheikhy, and Daroneh (2014) present Intellectual Capital as "a knowledge package that includes a set of intangible and invisible resources, principles, culture, behavior patterns, capabilities, competencies, structures, communications, processes, processes of knowledge. All knowledge is based on subjective perceptions. Entering the knowledge economy, knowledge is more preferable compared to other factors of production such as land, capital and machinery" [42] (p. 512).

However, to capitalize on the aforementioned knowledge package and to maintain competitive advantage, the company should always look for new knowledge and utilize it in new creative ways. This requires securing an organizational environment that will encourage individuals to employ and exploit this knowledge, taking into consideration that talented employees leave the organization if they are not satisfied with the total rewards, leadership and organizational policies etc. These problems occur when proper talent management practices are not in place [43]. However, to counter the impact of the aforementioned problems, organizations must guarantee the existence of proper motivation, understanding and resources. Hence, knowledge management and motivation management are key strategic elements for securing and sustaining the competi- 
tiveness of a company [44]. Moreover, Montano (2005) assert that knowledge "is one of the main organizational assets that increase the value of an organization, and that when appropriately applied can lead to the development of a new or improved products or services" [45] (p. 285). Knowledge is the bedrock that is supporting today's corporate strategies [46]. In knowledge based economy, "Intellectual Capital is the most critical asset of the organization" (Ramezan, 2011; cited in [38] p. 15). Consequently, and as Hejase, Haddad, Hamdar, Al Ali, Hejase, and Beyrouti (2014) assert, organizations should motivate employees to learn and share knowledge to sustain the value-adding process. "Employees need to be able to associate new obtained knowledge with special rewards, such as higher job security and personal satisfaction and fulfillment. After understanding and associating cost to benefits, people will start to see the psychological costs of change and learning as being less than the value they may attain from acquiring new knowledge" [47] (p. 1554).

\subsection{Process and Components}

Generally, a number of classification literatures ([20], [26] and [48]-[50]) divide Intellectual Capital into three categories:

1) External (Customer-Related) Capital,

2) Internal (Structural) Capital, and

3) Human Capital.

The aforementioned authors state that Intellectual Capital is based on various intangible resources, such as employees' competence, knowledge, education, skill, intellectual agility, brand name, customer relationship and organization structure, taking into consideration that Ismail (2005) added Spiritual Capital as the fourth component of Intellectual Capital [51], and that Bueno, Salvador, and Rodriguez (2004) [52] and $\mathrm{Wu}$ and Tsai (2005) [53] had extended the concept of Intellectual Capital in their research and introduced two more components, namely Social Capital and Technological Capital. However, Ramezan (2011) states that the components of Intellectual Capital are Human Capital, Organizational Capital (or Structural Capital), Technological Capital, Social Capital and Business Process Capital (or Customer Capital) [54]. Accordingly, the components of Intellectual Capital will be divided in this paper into fundamental components, Human Capital, Structural Capital, and Relational Capital; Spiritual Capital; Social Capital; and, Technological Capital. However, it is important to mention that some researches like Nemec Rudež (2005, pp. 325-326) classify Intellectual Capital into "A Two-Side Intellectual Capital Classification" and "A Three-Side Intellectual Capital Classification". The two-side classification consists of Human Capital and Structural Capital, while the three-side classification contains Human Capital, Structural Capital, and Relational Capital. So, there are several models or classifications that might be applicable for the study of Intellectual Capital [55].

\subsubsection{Human Capital}

Human Capital has been defined as the knowledge, skills, and abilities residing within and utilized by individuals [56]. Human Capital is the heart of Intellectual Capital. 
Human Capital (HC) is known as an organization's combined human capability for solving different business problems. It is inherent in employees and cannot be owned by a firm [49]. As the literature has indicated, HC focuses on competencies, attitudes and intellectual agility. So, Human Capital is made of different knowledge assets of the person, such as people knowledge backlog coming from training, skills, innovation and others [57]. This capital is a part of the underpinnings core competence of the organization [58]. Human Capital has been considered as the primary element of Intellectual Capital and the most important source of sustainable competitive advantage ([49], [59]). Moreover, Starovic and Marr (2004) discern that according to "guidelines produced by researchers from universities across Europe, collectively known as the Meritum Project, Human Capital is defined as the knowledge, skills and experience that employees take with them when they leave. Some of this knowledge is unique to the individual; some may be generic" [60] (p. 6). Human Capital also encompasses how effectively a firm uses its employees' resources as measured by innovation and creativity. Human Capital includes anything associated with the people within the organization. It includes elements such as employees' tacit knowledge, skills, experience and their attitude [61].

Based on the aforementioned definitions, it can be deduced that Human Capital is a major source of value addition in organizations as it is based on skills, knowledge and expertise, competence, attitude, and intellectual agility of employees. The improvement of Human Capital consists of a set of competencies which are necessary for using knowledge and skill in order to access outcomes of organizational programs. These competencies include features such as creativity, flexibility, leadership ability, problem solving ability, holding constructive relationships with others, entrepreneurship, and complex skills like "the knowledge of how to learn". "Since human capital is considered as the main stimulus for growth in this economy, it can determine the competitive status of a country. The successful development of this economy considerably depends on the quality of education and the educational system" [62].

\subsubsection{Structural Capital}

Structural Capital (SC) includes codified knowledge, procedures, processes, goodwill, patents, systems, information system, databases, hardware, software and culture. Some authors declare that $\mathrm{HC}$ creates SC and that the quality of SC is most likely a reflection of the quality of HC [49]. In contrast to Human Capital, Structural Capital (SC) is described by OECD (1999; cited in [63], p. 55) as "What is left after employees go home for the night”. Structural Capital of organizations represents all the nonhuman storehouses of knowledge, including databases, organizational charts, process manuals, strategies, routines and policies ([29], [53]). Jamshidy et al. (2014) referred to Moon and Kym (2006) who state that SC facilitates the use of available knowledge resources as a supportive infrastructure, databases and processes of the firm that enable the manager and employee to function and run the firm in order to implement and enhance the delivery of goods and services. While firms do not own HC, Structural Capital belongs to the firm as a whole [63]. 


\subsubsection{Relational Capital}

Several researchers [28] and [64] contend that Relational Capital comprises alliances, relationship with different stakeholders (such as customers, partners, suppliers, investors and so on) as well as franchises, trademarks, licenses, distribution networks, government bodies and agencies, image and brand, communities, public and environment. Roos, Bainbridge, and Jacobsen (2001) emphasize the importance of the relationship with customers to organizations because customers buy products or services from the enterprises [65]. This relationship is stressed by Ciemleja and Lāce (2008) as the basic principle of Customer Capital [66]; a notion shared by Tai-Ning, Hsiao-Chen, Shou-Yen, and ChiaoLun (2011) [67]. Such capital contains a customer base, knowledge about customers, and cooperation in terms of historical and future predictions. Customer Capital is considered a future income or cash flow from the current and potential customers. However, "it is a value that bases upon the reliable, sustainable and mutually beneficial relationships between the customer and enterprise and it is related to the investments from the enterprise. The value generation process is influenced by such elements: product or service price, quality and functionality; identification and reputation of the enterprise; interrelation position between customers and enterprise staff' [66] (p. 31).

Moreover, this kind of capital has also influence on networking and the relation function of the Board of Directors (BOD) within and outside the firm [68]. The BOD is seen as a potentially central resource for the firm, which especially plays a vital role between the firm and the different providers of resources, in particular the different resources for the operations of the firm [68]. It is very important for organizations to satisfy their customers' needs [67]. Therefore, Customer Capital is an important component of Intellectual Capital and is based on customer satisfaction, loyalty and network. However, Nemec Rudež (2005) divided Relational Capital into two categories [55]. Her justification is based on the fact that relationships with customers are crucial for service industries; and, that Customer or Relationship Capital should be separated from Structural Capital. To Rudež, what characterizes the services is the fact that it is very difficult to repair mistakes or improve the service after it is delivered to the customer. Therefore, service industries have critical soft skills needed to guarantee fast response to customers' complaints or customers' concerns including reliability, courtesy, attentiveness, helpfulness, care, friendliness, understanding the customers, responsiveness, and communications. Thus, according to Rudež, the importance of customer care indicates that the three-part intellectual capital classification is more adequate than the two-side one in service industries. "From the view of value creation, we found necessary to divide relationship capital into two parts:

- Customer Capital, defined as an asset shaped by relationships between the company and its customers; and,

- Non-customer Capital, defined as an asset shaped by relationships between the company and every subject in its environment but customers" [55] (p. 329).

\subsubsection{Other Components of Intellectual Capital}

In addition to the previously mentioned Intellectual Capital's components, several re- 
searchers and theorists have defined more components of IC.

\subsubsection{Spiritual Capital}

Jamshidy et al. (2014) referred to Zohar and Marshall (2004) and Ismail (2005) in their review about Spiritual Capital [63]. For example, Zohar and Marshall (2004) have applied the term "spiritual capital" as "the amount of spiritual knowledge and expertise available to an individual or a culture, adding that the word-spiritual-refers to meaning, values and fundamental purposes" [63] (p. 27). Spiritual Capital is identified by Ismail (2005) as "the intangible knowledge that includes faith, belief and emotion embedded in the minds and hearts of individuals and in the heart of the organization which includes vision and direction, principles, values and culture". He believes "the individual and organization behave and act with honor, integrity, sincerity, honesty, truth, trust, love, morals and ethics" [51] (p. 9). According to Isamil, Spiritual Capital also includes motivation, self-esteem, courage, strength, commitment, teamwork, determination, desire, enthusiasm and team spirit [51].

Spiritual Capital is considered a recent form of capital and is known as the newfound Intellectual Capital form of the firm and organization. Scholars (Verter, 2003; Zohar and Marshall, 2004; Metanexus Institute, 2006; all cited in [63], p. 56) have stated that it has arrived through three separate paths: sociological constructs; individual spiritual intelligence at the organizational level; and, quantification of the value of spirituality and religion in economic terms. However, according to Middlebrooks and Noghiu (2010), "Despite the fact that these three paths overlap, each of them offers a diverse conceptualization of spiritual capital, particularly at the operationalization level" [69] (p. 73).

\subsubsection{Social Capital}

According to Requena (2002), "possessing the elements of social capital is the sole most important indicator of quality work conditions and efficiency in an organization" [70] (p. 10). While, Ekinci (2008, p. 21; cited in [71]) contends that "the theoreticians who were influential in the conceptualization of social capital define it as a combination of trust, social networks, mutuality, values and norms, which guide people's cooperation and have a role in economic development and social well-being" (p. 212). Referring to the aforementioned definition, Social Capital is the basis of all social organizations, ranging from interpersonal relationships, groups, institutional and organizational structures to larger social segments. Accordingly, Çelik and Ekinci (2012) assert that "Social Capital grows in relation to value-based social relationships. The formation and strengthening of these values also depends on the relations between individuals and groups" [71] (p. 213). In their research about Social Capital and schools, they found that "of the dimensions of social capital, a positive relationship was observed between 'organizational commitment' and success groups” [71] (p. 221).

\subsubsection{Technological Capital}

According to De Castro, Navas López, García Muiñac, and Sáez (2004), “Technological Capital is composed of four basic elements: research, development, and innovation ( $R$ 
\& D \& I); technological infrastructure; intellectual and industrial property, and results of innovation" [72] (pp. 10-11). Longo-Somoza, Bueno and Acosta-Prado (2015) state that Technological Capital refers to the "combination of intangibles directly linked to the development of the activities and functions of the technical systems of operations, responsible for obtaining products with a series of specific attributes” [73] (p. 5).

\subsubsection{Managing Intellectual Capital}

The process to reach Successful Intellectual Capital Management was discussed by several authors and theorists. Marr (2008) gives a five-step process to succeed in managing Intellectual Capital, namely, identifying, mapping, measuring, managing, and reporting Intellectual Capital as shown in Exhibit 1 [74].

Exhibit 1. Five steps to manage Intellectual Capital, [74].

The first step: An inventory check. It requires the identification of an organization's Intellectual Capital. The categorization of Intellectual Capital can be used to facilitate a discussion about the current stock of intangibles. It can be used to create a template that informs people about the different categories of Intellectual Capital, and prompts them to think about their organizations' different types of intangibles. Intellectual Capital can be identified through conducting interviews, facilitated workshops, or via mail or online surveys.

Second step: Mapping the Intellectual Capital Value Drivers: A value creation map is a visual representation of the organizational strategy. Mapping the key value drivers into a visual map has two primary functions. The first is to ensure that the strategy with all its Intellectual Capital value drivers is integrated and coherent; the second is to enable easy communication of the strategy and the role and importance of Intellectual Capital in delivering the strategy. A value creation map brings together the three key elements of an organizational strategy, namely, its value proposition, its core activities, and its enabling strategic elements or performance drivers.

Third step: Measuring Intellectual Capital: After identifying and mapping the Intellectual Capital value drivers, organizations can start measuring them. Many tools and techniques are available to measure Intellectual Capital.

Fourth step: Managing Intellectual Capital: Measures allow organizations to manage Intellectual Capital. Without relevant assessments, it is impossible to understand current performance levels, know whether the Intellectual Capital has improved or deteriorated, and understand whether any activities and initiatives have affected performance. Organizations that have meaningful performance information about its Intellectual Capital can use it to inform decision making, to test and review strategy, and to manage risks associated with Intellectual Capital.

Fifth step: Reporting Intellectual Capital: The final step is to report the Intellectual Capital. Disclosing the value of Intellectual Capital can be done for different reasons. However, they all share one key objective, which is to provide information about the Intellectual Capital of an organization to its stakeholders.

Although Intellectual Capital is similar to tangible assets in its potential for generating future cash flows, Talukdar (2008) sees that it is radically different from Tangible 
Capital in the following respects [75]:

- "Intellectual Assets are non-rival assets. Unlike physical assets which can only be used for doing one thing at a time, Intellectual Assets can be multiplexed.

- Human Capital and Relational Capital cannot be owned, but have to be shared with employees and suppliers and customers.

- Structural Capital is an intangible asset that can be owned and controlled by managers.

- Structural Capital, in the form of just-in-time procurement processes and real time inventory control systems can be substituted for expensive capital expenditure such as storage warehouses.

- Firms that leverage their Intellectual Capital to do knowledge work are able to generate higher margin of profits than those who provide mass-produced solutions.

- Human, Structural and Relational Capital often work together in judicious combinations to give rise to core competencies that assume strategic significance. Hence, it is not enough to invest in people, systems and customers separately, but in combinations that produce end value" [75] (p. 2).

\subsection{Methods and Applications}

Müller (2004) contends that "when evaluating available measurement methods, one will furthermore recognize that there exists a strong emphasis on the strategic aspect of Intellectual Capital. The metrics of IC that are delivered are often highly aggregated. Consequently, their capability to transport good information about the operational aspect of Intellectual Capital is rather restricted" [76] (p. 8), noting that Neely, Marr, Roos, Pike and Gupta (2003) identify in their research a third generation of measurement systems [77]. However, they offer an insight which states that first generation measurement systems, which were financially biased, were supplemented with non-financial indicators, including intangibles. These systems were static and failed to adequately illustrate the linkage between different performance measures. Later on, second generation measurement systems offered an improvement to the first by "using strategy and/or success maps to take into account the dynamic nature of performance and the transformation processes linking objectives and resources" [77] (p. 129). The proposed third generation measurement systems will build on the aforementioned developments and "seek to link, explicitly, the non-financial and intangible dimensions of business performance to the generation of free cash flow" [77].

Measuring Intellectual Capital helps to "recognize organizational knowledge's flows and critical knowledge issues; to accelerate the learning patterns; identify best practices; diffuse them across the firm; and, to increase innovation and collaborative activities" (Kannan and Aulbur 2004; cited in [78], p. 340). There exist many reasons which incite an organization to measure Intellectual Capital; these reasons can be classified into two groups: internally oriented reasons and externally oriented ones [78] (p. 340). External reasons include a better public image, an increase in market value, a reduction of the difference between market and book value, and additional information for potential 
investors and the market. While internal reasons include decision making, overall business success, the connection between investments in intangibles and business goals as well as the necessity to manage them [78].

Different categories of Intellectual Capital measurement methodologies can be distinguished, and all have their pros and cons. The most structured approach of presenting the available methods was developed by Sveiby (2010). The methods are classified into four groups based on the level of measurement and the way of evaluation. These are: Market Capitalization, Return on Assets, Scorecard and Direct Intellectual Capital Methods [79].

Nowadays, many corporations around the world have found that measuring and managing Intellectual Capital can provide them with a competitive advantage. Although there are several Intellectual Capital Measurement Methods it must be considered that calculated intangible value is not precise. However, Sveiby (2010) offers the following recommendations whereby he matched measuring approaches to measuring motives:

“1) Monitor Performance (Control). Best are Baldrige award-type of performance indicators and KPIs.

2) Acquire/Sell Business (Valuation). Best are Industry rules-of-thumb (\$ per click, $\$$ per client, brand valuation).

3) Report to Stakeholders (Justification, PR). Best are IC supplements, EVA, Triplebottom line.

4) Guide Investment (Decision). None of the intangibles approaches can beat traditional Discounted Cash Flow.

5) Uncover Hidden Value (Learning). Best are score cards and Direct IC methods" [79] (Para 17).

No one method can fulfil all purposes; one must select a method depending on purpose, situation and audience. Gogan (2014) contends that "properly using Intellectual Capital Measurement Methods can cause the creation of competitive advantage consequently create development of the whole company" [80] (p. 175).

\subsection{Benefits}

The role of Intellectual Capital is important inside small and medium enterprises; the main reason is their influence on formulation and implementation of strategies in these enterprises. "Companies with strong Intellectual Capital have the chance to recruit and retain higher quality personnel” [81] (p. 242). Nowadays, organizations need to utilize all their resources, both tangible as well as intangible assets, to gain competitive advantage [82]. "The importance of Intellectual Capital is highly recognized as a successful factor not only in knowledge-intensive organizations, but also for most other types of organizations" (Lonnqvist and Mettanen, 2002; cited in [83], p. 341).

Other studies have revealed that Intellectual Capital is positively and significantly related to organizational performance ([18], [29], and [84]) and to innovation, and competitiveness ([82], [85]-[87]). On the other hand, the interaction between innovation, 
knowledge management and Intellectual Capital has also been studied ([88]-[91]), and was concluded that managers have the opportunity to take necessary actions and give a better direction to their enterprises where they are informed about their organization's Intellectual Capital. According to Guthrie, Petty, and Ricceri (2006), Intellectual Capital definitely, "enlightens investors and shareholders with a broader perspective about the growth and improvement trend as well as potential of an organization [92]. Parallel to this issue, it is stated that sharing Intellectual Capital information of companies is also advantageous for the economy of nations, since investments are allocated much better" [92] (p. 254). Also, Rexhepi, Ibraimi, and Veseli (2013) contend that Intellectual Capital provides managers with the big picture and serves as an essential part of firm strategy [93]. Rexhepi et al. (2013) refer to Wu (2005) by stating that nowadays, "competitive advantage, material and financial resources of enterprises, depend on how organizations conduct their Intellectual Capital" [93] (p. 45). Furthermore, the aforementioned authors confirm other researchers point of view that "the future of a business move is to create values of working people; business strategy, structure, systems and processes, established by the enterprise and customer community are only possible with effective management of Intellectual Capital” [93] (p. 45).

The value organizations obtain from their Intellectual Capital is the result of wellreasoned, well-planned and well-executed set of management initiatives [94]. Hamzah and Ismail (2008) assert that "different approaches to competition require different resources; and these different resources need to be managed differently to ensure that they create the desired value. Hence, the importance of intellectual capital as a resource must be managed effectively" [95] (p. 242). Laing, Dunn, and Lucas (2010) examine the relationship between IC and financial performance of Australian hotel industry and argue that IC performance is one of the strategic assets. The study concludes that the measured financial performance heavily depends on Human Capital Efficiency (HCE), which indicates efficient staff has great capability to boost the financial performance of any organization through their effective decision making [96]. The aforementioned relationship was also confirmed by Ul-Rehman, Asghar, and Ur Rehman (2013) [97].

In their book "Managing Intellectual Capital in Practice", Roos, Pike, and Fernström (2006) state that the proper and efficient management of Intellectual Capital will increase transparency in the financial market which may result in lower weighted cost of capital and therefore a higher market capitalization [98]. This also helps create trust among employees and other stakeholders. In addition, it will support the long-term vision of the company since Intellectual Capital reporting is about long-term perspectives. Marr (2008) shows that Intellectual Capital helps to drive success and create value [74]. Although physical and financial assets remain important, Intellectual Capital elements such as the right skills and knowledge, a respected brand and a good corporate reputation, strong relationships with key suppliers, the possession of customer and market data, or a culture of innovation, set enterprises apart. According to Andrews (2009), the Intellectual Capital component is not well understood; it is a "black hole" of strategic analysis [99]. The key challenge in Intellectual Capital Management is transforming intangible assets into something that creates value for the organization using 
Dynamic Capability. Dynamic Capability is the ability to achieve new forms of competitive advantage by appropriately adapting, integrating, and reconfiguring intangible assets (organizational skills, resources, and competencies). Understanding intangible assets provides new strategic insights and competitive options for supply chain design and operation.

Talukdar (2008) explains that the tangible assets can be acquired by just about any business which has enough money to buy such assets [75]. However, intangible assets have to be cultivated, nourished and nurtured in a planned manner before their yield can be fully harvested. The real differentiator between one firm and the next therefore is the readiness of the firm's intangible assets for converting its tangible assets to cash in the most efficient manner. This readiness is more commonly known as core competency in business texts and is the chief source of competitive advantage for companies.

\subsection{Constraints}

Part of the problem in managing Intellectual Capital is that many organizations do not understand its underlying power. In fact, value creation results from the interaction of the components of Intellectual Capital; for example, the ability to take a human skill or expertise and transform it into a structural asset. For instance, a marketing employee who has developed a method of handling customers efficiently can be encouraged to document his/her method so that other marketers can learn it. In some cases, the method can form the basis of an expert system in which technology can be an enabler that makes the process accessible to others. Converting skills into an organizational asset in this way illustrates the dynamic potential of managing Intellectual Capital. It can be interpreted as a means of capturing the tacit knowledge of the individual and making it explicit in the organizational structure [100]. In his article, "Intellectual Capital: A Human Resources Perspective", Adelman (2010) states that "Human Resources Professionals and Managers have a major challenge to obtain and store information about

- Core job knowledge of all employees, their experience, and their key skill-sets.

- Training is perhaps more important than ever.

- Performance review systems are based upon meaningful metrics.

- Development of effective succession planning systems.

- Leadership and management development programs" [12] (Para 11).

\section{Research Methodology}

This research is exploratory in nature, using a convenient sample based on the willingness of the respondents to participate and volunteer their time to respond to the questionnaire. The research was carried out in the period extending from July 2014 to June 2015.

\subsection{Questionnaire Design}

The questionnaire includes a statement describing the information to be collected followed by a statement of confidentiality in which the researchers introduced themselves to the respondents. The questionnaire consists of 45 questions divided into six parts. 
Different styles of closed questions are used including dyadic, multiple choice, and fivelevel Likert scale questions. The six parts are explained herein,

- The first part consists of seven demographic questions.

- The second part consists of ten questions related to the technical knowledge of the subject. It helps to assess the level of employee's awareness of Intellectual Capital Management.

- Third part consists of six five-level Likert scale questions regarding the "Financial Benefits" and their impact on employee's retention. It identifies the degree of the satisfaction with the level of financial benefits.

- The fourth part consists of ten five-level Likert scale questions related to the "Non-financial Benefits". It focuses on listing the degree of satisfaction with several benefits such as Job Security, Work Environment, Team Work, and Work-Life Balance.

- The fifth part consists of ten questions designed to assess the employees' awareness of the work's roles, tasks, conditions, and responsibilities.

- The final part consists of six questions whose aim is to assess Knowledge Management concept, and check whether employees are familiar with this concept or not. It will also identify the most effective way to gain knowledge based on employees' response.

\subsection{Sample Selection and Size}

Non probability sampling is any procedure in which elements do not have the equal opportunities of being included in a sample. The set target was to collect 300 questionnaires. First, the questionnaire was published on Surveymonkey.com through the link: https://www.surveymonkey.com/s/XC5TNV9, and then shared by the researchers (to employees-people who work) through LinkedIn, Research Gate, and Personal E-mails. After this, and from the total of 286 respondents, a total of 258 questionnaires were completely filled out. 28 questionnaires were excluded due to incompleteness or due to inappropriate filling, that is, responses selected haphazardly. Thus, the response rate is $86 \%$. It is worth mentioning that $36.82 \%$ of the people who had filled out the questionnaire are females and $63.18 \%$ are males. Their age range is mostly between 25 and 34 .

\subsection{Data Analysis}

All responses were entered to the SPSS program "Statistical Product and Service Solutions, an IBM product acquired by IBM in 2009 [101] (p. 58). The study was performed using exploratory statistics; data tables including frequency and percentage distributions were used and supported by their respective figures. Moreover, cross tabs were performed to study relationships between variables that may add value to the findings of the research.

\section{Results and Findings}

This section delineates the results in the form of exploratory statistics. Results and 
findings are presented in the same order as that of the sections of the questionnaire.

\subsection{Demographic Analysis}

$63.18 \%$ of the respondents are males (163 persons) and $36.82 \%$ are females (95 persons); $50.8 \%$ of the respondents are between 25 and 34 years old, $12.8 \%$ are between 18 and 24 years old, and $23.3 \%$ are between 35 and 44 years old. The remaining percentage consists of those older than 45 years. Also, $49.6 \%$ of the respondents are single, and $47.7 \%$ are married. Moreover, $43.8 \%$ of the respondents hold a Bachelor Degree (BA/BS), and $37.6 \%$ hold a Master's Degree (MBA/MS/MA), while $8.9 \%$ hold a high school degree and $9.7 \%$ hold a $\mathrm{PhD}$.

Furthermore, $13.2 \%$ of the respondents are first line managers, $31.4 \%$ are middle managers, $21.3 \%$ are senior/executive managers, $3.9 \%$ are owners, and $19.4 \%$ hold non-managerial positions. It is important to mention that there is $10.9 \%$ who are university professors and advisors. In addition, $52 \%$ of the respondents work in the service industry, including consulting, education, information technology, and pharmaceutical companies; $30 \%$ work in Retail/Wholesale business; $9 \%$ in food production; $3 \%$ in government; and, $6 \%$ in engineering. Finally, $38.8 \%$ of the respondents have been with the company for a period from 1 to 5 years, $24.8 \%$ have 6 to 10 years of experience, $15.5 \%$ are new joiners, $10.1 \%$ have 11 to 15 years of experience, and $10.8 \%$ have been for more than 16 years at the company.

\subsection{Awareness about Intellectual Capital Management}

The aim of this section is to identify the degree of awareness of different related concepts, such as Knowledge Management, Human Capital, and Intellectual Capital.

When respondents were asked about their awareness of the term "Intellectual Capital", $77.52 \%$ (200/258) answered positively; and, when asked regarding their awareness of all the company's policies and procedures, $88.37 \%$ confirmed. Also, $93.41 \%$ feel that Human Capital is considered a valuable asset at the company, and $93.02 \%$ of the respondents confirmed that their technical and soft skills have improved during their current jobs. In addition, $97.67 \%$ of the respondents (252 persons) are aware of the importance of Human Resources (HR) Management, and $92.25 \%$ of the total respondents are familiar with the roles, tasks, and responsibilities of HR Department. However, only $54.65 \%$ of the respondents (141 persons) have attended a training/conference on HR concepts.

Moreover, out of 258 respondents, 176 persons are working at a company where the HR Department is divided into divisions/sections. 220 employees (85\%) have confirmed that open communication is encouraged at the company they work at, and the remaining 38 persons (14.72\%) do not think this is applicable at their companies.

When employees were asked about the existence of awareness on Employee Retention methods at the company, $71.32 \%$ of them (184 out of 258) said that these methods exist; however, $28.68 \%$ of them (74 out of 258 ) denied such fact.

\subsection{Financial Benefits}

Table 1 illustrates the different questions asked regarding the importance of the Finan- 
cial Benefits for employees. Responses are presented as three categories for the sake of clarity and comparability of details whereby "Strongly Agree and Agree" are labeled as "A: Agreement" and "Strongly Disagree and Disagree" are labeled as "D: Disagreement" while keeping " $\mathrm{U}$ : Uncertain" as is.

Table 1 shows that respondents are marginally satisfied with their financial benefits (56.20\%), with their salaries as compared to their peers (60.90\%), and to their counterparts in similar jobs (53.10\%). A similar satisfaction is observed as to their promotion prospects $(52.70 \%)$.

\subsection{Non-Financial Benefits}

In the questionnaire, several non-financial benefits have been evaluated in order to assess the degree of satisfaction of respondents. First of all, $67.80 \%$ of the respondents agree that "Job Security" is ensured at the company they work at. In addition, $70.90 \%$ of them confirm that the work environment of the company is healthy and positive. "Work-Life Balance" is applicable at 59.3\% of the respondents' companies/jobs. $69.80 \%$ of surveyed employees (180 out of 258 persons) agree that Team Work level is high and is encouraged by managers. The companies of 143 respondents $(55.40 \%)$ have a program to show appreciation to employees. The current company's culture and values are adaptable for $72.50 \%$ of respondents. "Non-Financial Benefits" (such as Job Security, Appreciation, Career Path and Healthy Environment) are essential and very important for (241/258) $93.40 \%$ of surveyed employees. However, only 127 out of 258 (49.20\%) have stated that they will stay at the company they work at whatever the financial benefit is.

\subsection{Work Roles and Responsibilities/Job Conditions}

This part aims to analyze the degree of satisfaction with the work conditions as well as the degree of commitment to the company/team. In response to the sentence "I'm happy working with the members of the group", $89.14 \%$ of the respondents answered with "Yes". Moreover, $93.02 \%$ of the respondents like the nature of their jobs. 81.78\% are satisfied with the duties and responsibilities assigned to them. Also, $72.48 \%$ of the respondents claim that the work schedules are flexible, $72.86 \%$ of the respondents believe that their workload is fair, and only $67.05 \%$ of the respondents said that they are given the sufficient training opportunities at the current company.

Table 1. Importance of the financial benefits for employees.

\begin{tabular}{cccc}
\hline Statement & A & U & D \\
\hline Salary is fair compared to counterparts in similar jobs & $53.10 \%$ & $23.30 \%$ & $23.60 \%$ \\
Salary is fair compared to peers within the organization & $60.90 \%$ & $20.50 \%$ & $18.60 \%$ \\
I'm satisfied with the company's financial benefits & $56.20 \%$ & $20.50 \%$ & $23.30 \%$ \\
The salary adjustment granted to me reflects my level of performance & $43.80 \%$ & $26.40 \%$ & $29.80 \%$ \\
Promotion prospects in the company are acceptable & $52.70 \%$ & $21.70 \%$ & $25.60 \%$ \\
Financial benefits are the most important benefits to retain employees & $45.00 \%$ & $16.20 \%$ & $38.80 \%$ \\
\hline
\end{tabular}




\subsection{Knowledge Management}

This section analyzes the ability to manage the employee's knowledge within the current job. $82.6 \%$ of the respondents confirm that their jobs' environments help them increase their knowledge. $91.10 \%$ of employees (235 out of 258) agree with the fact that having an effective Knowledge Management applied on the company's Human Capital will give the company a competitive advantage among other companies within the same industry.

Also, 164 out of 258 surveyed people (63.56\%) agree that the company they work at gives attention to Knowledge Management. Almost the same rate of respondents (63.95\%) agrees that the company cares about the knowledge of the workers. Also, $84.90 \%$ of the respondents (219 persons) confirm that they are able to increase and manage their knowledge during their work.

Table 2 shows the distribution of responses when respondents were asked to choose the most effective way to increase their knowledge. Multiple responses were allowed.

Table 2 depicts several responses whereby the top three responses were: $22.70 \%$ chose "Work Experience", 18.58\% chose the "Internet", and 15.17\% "On-Job Training".

\subsection{Cross Tabulations}

When conducting survey analysis, cross tabulations (also referred to as cross-tabs) are a quantitative research method appropriate for analyzing the relationship between two or more variables. Cross tabulations provide a way of analyzing and comparing the results for one or more variables with the results of another (or others) [102].

Results show that $50.38 \%$ ( 130 out of 258 ) of the respondents like the nature of their jobs and also agree that their salaries are fair as compared to counterparts in similar jobs in other organizations; while $21.31 \%$ (55 out of 258 ) like the nature of their jobs but think that the salary is not fair as compared to counterparts in similar jobs in other organizations. However, when the aforementioned statements are cross tabulated, no statistical significance is obtained (see Table 3 ). Similar results are obtained when studying the Cross-tab "I like the nature of my job" versus "The salary is fair compared to my peers within the organization". Results show that $58.91 \%$ (152 out of 258 ) of the

Table 2. Effective ways to increase knowledge.

\begin{tabular}{ccc}
\hline Method & Respondents & Percentage \\
\hline My work experience & 193 & $22.70 \%$ \\
Internet & 158 & $18.58 \%$ \\
On-job Training & 129 & $15.17 \%$ \\
Books/Readings & 121 & $14.23 \%$ \\
Educational Programs & 120 & $14.11 \%$ \\
My manager/supervisor & 112 & $13.17 \%$ \\
Other & 17 & $2.00 \%$ \\
Total & 850 & $100 \%$ \\
\hline
\end{tabular}


respondents like the nature of their jobs and their salaries are fair as compared to their peers within the organization; while $17.05 \%$ (44 out of 258) like the nature of their jobs but think that the salary is not fair as compared to their peers within the organization. However, the crosstab in question has no statistical significance (see Table 3).

Furthermore, the cross-tab "I like the nature of my job" versus "I am satisfied with the company's financial benefits" shows that $54.26 \%$ (140 out of 258 ) of the respondents like the nature of their jobs and are satisfied with the company's financial benefits; while $20.15 \%$ (52 out of 258) like the nature of their jobs but are dissatisfied with the company's financial benefits. Here, although Pearson's R indicates a weak and negative correlation, the crosstab in question has statistical significance (see Table 3).

\subsection{Other Crosstabs Lead to the Following Results}

Cross-tab "I like the nature of my job" versus "The salary adjustment granted to me reflects my level of performance" show that $42.63 \%$ (110 out of 258) of respondents like the nature of their jobs and that the salary adjustment granted to them reflects their level of performance; while $26.35 \%$ (68 out of 258) like the nature of their jobs but the salary adjustment granted to them does not reflect their level of performance. Here, Table 3 shows that Pearson's R indicates a weak and negative correlation and there is statistical significance to the cross tab in question since the calculated error is 0.009 less than $5 \%$.

Cross-tab "I like the nature of my job" versus "The promotion prospects in the company are acceptable" shows that 51.93\% (134 out of 258) of the respondents like the nature of their jobs and the promotion prospects in the company are acceptable to them; while $21.31 \%$ (55 out of 258) like the nature of their jobs but the promotion prospects in the company are not acceptable to them. In addition, Pearson's $\mathrm{R}$ indicates a weak and negative correlation and one may observe that there is a statistical significance to the cross tab in question since the calculated error is 0 less than $5 \%$ (see Table 3 ).

Table 3. Cross-tab results.

\begin{tabular}{|c|c|c|c|}
\hline Crosstab & Pearson's R & App. Sig. & Stat. Sig. \\
\hline $\begin{array}{l}\text { "I like the nature of my job" versus "The salary is fair compared to my } \\
\text { counterparts in similar jobs" }\end{array}$ & -0.100 & 0.110 & No \\
\hline $\begin{array}{l}\text { "I like the nature of my job" versus "The salary is fair compared to my } \\
\text { peers within the organization" }\end{array}$ & -0.121 & 0.053 & No \\
\hline $\begin{array}{l}\text { "I like the nature of my job" versus "I am satisfied with the company's } \\
\text { financial benefits" }\end{array}$ & -0.209 & 0.001 & Yes \\
\hline $\begin{array}{c}\text { "I like the nature of my job" versus "The salary adjustment granted to } \\
\text { me reflects my level of performance" }\end{array}$ & -0.162 & 0.009 & Yes \\
\hline $\begin{array}{l}\text { "I like the nature of my job" versus "The promotion prospects in the } \\
\text { company are acceptable" }\end{array}$ & -0.265 & 0.000 & Yes \\
\hline $\begin{array}{l}\text { "I like the nature of my job" versus "I'm satisfied with the duties and } \\
\text { responsibilities assigned to me" }\end{array}$ & 0.304 & 0.000 & Yes \\
\hline $\begin{array}{c}\text { "Human Capital is considered a valuable asset at the company" versus } \\
\text { "Job Security is ensured at the company" }\end{array}$ & -0.155 & 0.013 & Yes \\
\hline
\end{tabular}

Note: Approx. Sig. is compared to the standard error $\alpha=5 \%$. 
Cross-tab "I like the nature of my job" versus "I'm satisfied with the duties and responsibilities assigned to me" shows that $79.06 \%$ (204 out of 258) of the respondents like the nature of their jobs and are satisfied with the duties and responsibilities assigned to them. The crosstab in question is valid since Pearson's $\mathrm{R}=0.304$ indicates a moderate and positive correlation and the calculated error is much less than $5 \%$ (see Table 3).

Cross-tab "Human Capital is considered a valuable asset at the company" versus "Job Security is ensured at the company" shows that $64.72 \%$ (167 out of 258 ) of the respondents confirm that the company considers Human Capital as a valuable asset, and that the Job Security is ensured at the company; while 13.17\% (34 out of 258) confirm that the company considers Human Capital as a valuable asset but does not ensure Job Security. Moreover, Pearson's R equals to -0.155 , which indicates a weak and negative correlation; however, there is statistical significance to the cross tab in the question since the calculated error is 0.013 less than $5 \%$ as shown in Table 3.

\subsection{Regression Analysis}

According to Hejase \& Hejase (2013) a "Multiple Regression Model is needed when the researcher faces the scenario where more than one independent variable causes variations in the dependent variable under study" [101] (p. 478). Therefore, the next step is to construct possible relationships which may help analyze the impact of "Financial" and "Non-financial" benefits on either employees or organizational factors.

\subsubsection{Regression Model One}

Dependent Variable: The company ensures a career path for all employees (Equal Opportunities are ensured for all).

Independent Variables: "My technical and soft skills have improved during my current job", "The salary adjustment granted to me reflects my level of performance", "The promotion prospects in the company are acceptable", "The company work environment is healthy and positive", and "Human Capital is considered a valuable asset at the company".

Tables 4-6 provide the technical information necessary to describe the regression model. Table 4 shows the Model Summary. Results indicate that the model is quantitatively suitable due to the strong and marginal values of the coefficient of correlation $(\mathrm{R}=$ $0.715)$ and the coefficient of determination $\left(R^{2}=0.511\right)$, respectively; however, the

Table 4. Model summary.

\begin{tabular}{|c|c|c|c|c|c|c|c|c|c|c|}
\hline \multirow[b]{2}{*}{ Model } & \multirow[b]{2}{*}{$\mathbf{R}$} & \multirow[b]{2}{*}{$\begin{array}{c}\mathbf{R} \\
\text { Square }\end{array}$} & \multirow[b]{2}{*}{$\begin{array}{l}\text { Adjusted } \\
\text { R Square }\end{array}$} & \multirow{2}{*}{$\begin{array}{c}\text { Std. } \\
\text { Error } \\
\text { of the } \\
\text { Estimate }\end{array}$} & \multicolumn{5}{|c|}{ Change Statistics } & \multirow[b]{2}{*}{ Durbin-Watson } \\
\hline & & & & & $\begin{array}{c}\text { R } \\
\text { Square } \\
\text { Change }\end{array}$ & $\begin{array}{c}\mathrm{F} \\
\text { Change }\end{array}$ & $\begin{array}{c}\mathrm{df} \\
1\end{array}$ & $\begin{array}{c}\mathrm{df} \\
2\end{array}$ & $\begin{array}{c}\text { Sig. F } \\
\text { Change }\end{array}$ & \\
\hline 2 & $0.715^{*}$ & 0.511 & 0.502 & 0.781 & 0.511 & 52.725 & 5 & 252 & 0.000 & 2.044 \\
\hline
\end{tabular}

*Predictors: (Constant), Human Capital is considered a valuable asset at the company. The salary adjustment granted to me reflects my level of performance. My technical and soft skills have improved during my current job. The promotion prospects in the company are acceptable. The company's work environment is healthy and positive. 
Table 5. ANOVA.

\begin{tabular}{ccccccc}
\hline \multicolumn{1}{c}{ Model } & Sum of Squares & df & Mean Square & F & Sig. \\
\hline \multirow{2}{*}{2} & Regression & 160.763 & 5 & 32.153 & 52.725 & $0.000^{*}$ \\
& Residual & 153.675 & 252 & 0.610 & & \\
& Total & 314.438 & 257 & & & \\
\hline
\end{tabular}

*Predictors: (Constant), Human Capital is considered a valuable asset at the company. The salary adjustment granted to me reflects my level of performance. My technical and soft skills have improved during my current job. The promotion prospects in the company are acceptable. The company's work environment is healthy and positive.

Table 6. Coefficients.

\begin{tabular}{|c|c|c|c|c|c|c|}
\hline & \multirow[t]{2}{*}{ Model } & \multicolumn{2}{|c|}{$\begin{array}{l}\text { Unstandardized } \\
\text { Coefficients }\end{array}$} & \multirow{2}{*}{$\begin{array}{c}\text { Standardized } \\
\text { Coefficients }\end{array}$} & \multirow[t]{2}{*}{$\mathbf{t}$} & \multirow[t]{2}{*}{ Sig. } \\
\hline & & B & Std. Error & & & \\
\hline \multirow{6}{*}{2} & (Constant) & 0.009 & 0.163 & & 0.057 & 0.955 \\
\hline & $\begin{array}{l}\text { My technical and soft skills have } \\
\text { improved during my current job. }\end{array}$ & -0.298 & 0.194 & -0.069 & -1.534 & 0.126 \\
\hline & $\begin{array}{l}\text { The salary adjustment granted to me } \\
\text { reflects my level of performance. }\end{array}$ & 0.208 & 0.056 & 0.198 & 3.746 & 0.000 \\
\hline & $\begin{array}{l}\text { The promotion prospects in the } \\
\text { company are acceptable. }\end{array}$ & 0.386 & 0.058 & 0.357 & 6.659 & 0.000 \\
\hline & $\begin{array}{c}\text { The company's work environment is healthy } \\
\text { and positive. }\end{array}$ & 0.325 & 0.059 & 0.298 & 5.500 & 0.000 \\
\hline & $\begin{array}{l}\text { Human Capital is considered a valuable asset } \\
\text { at the company. }\end{array}$ & -0.215 & 0.210 & -0.048 & -1.025 & 0.307 \\
\hline
\end{tabular}

Dependent Variable: The company ensures a career path for all employees (Equal Opportunities are ensured for all).

model is also qualitatively acceptable and statistically significant with F-value $=52.725$ with an associated probability of Zero (which is less than $\alpha=0.05$ ). Table 5 shows the results of ANOVA testing which indicate that the regression equation predicts better than would be expected by chance. The F-value $=52.725$ with an associated probability of Zero which is less than $\alpha=0.01$.

Table 6 shows the comparison of explanatory variables:

\section{My technical and soft skills have improved during my current job:}

This variable has a regression standardized weight of -0.069 . However, is not statistically significant since sig. $=0.126>\alpha=5 \%$. Therefore, it is excluded.

\section{The salary adjustment granted to me reflects my level of performance:}

This variable has a regression standardized weight of 0.198 and is statistically significant since sig. $=0.000<\alpha=5 \%$. Therefore, it is included.

This means that for the variable "The salary adjustment granted to me reflects my level of performance", as this variable increases by one standard deviation (SD), the dependent variable "The company ensures a career path for all employees" increases by $19.8 \%$ of a SD. This direct relation implies that the more respondents feel that their salaries are adjusted based on their level of performance, the more they will feel assured of a career path with the company.

\section{The promotion prospects in the company are acceptable:}


This variable has a regression standardized weight of 0.357 and is statistically significant since sig. $=0.000<\alpha=5 \%$. Therefore, it is included.

This means that for the variable "The promotion prospects in the company are acceptable", as this variable increases by one standard deviation (SD), the dependent variable "The company ensures a career path for all employees" increases by $35.7 \%$ of a SD. This direct relation implies that the more respondents feel that the promotion prospects in the company are acceptable, the more they will feel assured of a career path with the company.

The company's work environment is healthy and positive:

This variable has a regression standardized weight of 0.298 and is statistically significant since sig. $=0.000<\alpha=5 \%$. Therefore, it is included.

This means that for the variable "The company's work environment is healthy and positive", as this variable increases by one standard deviation (SD), the dependent variable "The company ensures a career path for all employees" increases by $29.8 \%$ of a SD. This direct relation implies that the more respondents feel that the company's work environment is healthy and positive, the more they will feel assured of a career path with the company.

\section{Human Capital is considered a valuable asset at the company.}

This variable has a regression standardized weight of -0.048 . However, is not statistically significant since sig. $=0.307>\alpha=5 \%$. Therefore, it is excluded.

\subsubsection{Resultant Model}

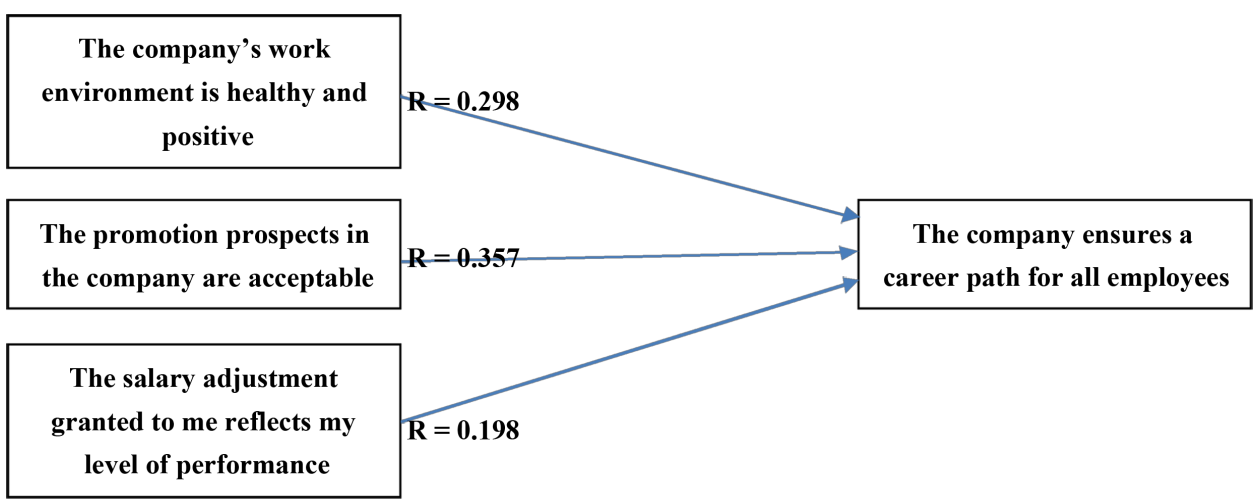

The Regression Model of results emphasizes the fact that when the company's work environment is healthy and positive and has clear policies for salaries and promotions, it can assure equal opportunities for growth and a clear career plan for its employees. Consequently, it is the view of this study that sustained efforts to keep active work environment, clarity of responsibilities and duties, and a positive way of communication will promote organizational readiness to implement retention planning frameworks and consequently enrich human capital.

\subsubsection{Summary of Major Findings}

The purpose of the research is to assess the extent of employees' awareness of the con- 
cept and applications of Intellectual Capital, and to explore the impact of financial and non-financial benefits on the "Employee Retention". Results show that $22.48 \%$ of the surveyed employees are not aware of the term "Intellectual Capital"; a response that is considered a positive sign because companies do not really address this concept in a direct manner.93.41\% of the respondents feel that Human Capital is considered a valuable asset at the company. In addition $97.67 \%$ are aware of the importance of Human Resources Management. On the other hand, $93.41 \%$ agree that Non-financial Benefits ensured by the company are very important and essential for employees to be satisfied with their job. However, only $49.22 \%$ of the surveyed employees will stay at the company mainly because of the Non-financial Benefits rather than the Financial Benefits. $56.2 \%$ of the employees surveyed are satisfied with the company's financial benefits. Moreover, $67.05 \%$ of the respondents stated that they are given the sufficient training opportunities. Likewise, the researcher has noticed that 193 employees under survey consider "Their Work Experience" as the most effective way to increase their knowledge. "Internet" comes then with 158 votes. "On-job Training" came third with 129 answers. Fourth comes the "Books and Readings" with 121 answers. Then come "Educational Programs" and "Direct Manager/Supervisor" with 120 and 112 votes respectively. However, $84.88 \%$ of the respondents stated that they are able to increase and manage their knowledge during their work. The greatest part of the respondents are educated professionals with the age range between 25 - 34, in the beginning of career with their current employer/organization, and occupying managerial as well as nonmanagerial positions at companies with different industries. The majority of them (31.01\%) are working with Retail/Wholesale industries.

\section{Conclusions and Recommendations}

In a dynamic, challenging, and fast-moving labor market, it is very important for companies to retain their Intellectual Capital. Dess, Lumpkin, and Eisner (2008) contend that "in today's knowledge economy, it does not matter how big your stock of resources is-whether it be top talent, physical resources, or financial capital. Rather, the question becomes: How good is the organization at attracting top talent and leveraging that talent to produce a stream of products and services valued by the marketplace?” [103] (p. 124). Companies should focus on granting employees both financial and non-financial benefits. Based on the aforementioned, it is imperative to have a strong HR team at the company to set fair policies and procedures. In addition, the company's culture should be adaptable to all the employees as this will strengthen the common view towards the vision of the company. Dess and Lumpkin (2001) contend that successful firms are well aware that the attraction, development, and retention of talent is a necessary but not sufficient condition for creating competitive advantages [104]. Also, Dess et al. (2008) stress that the talented people's "skills and attitudes must be continually developed, strengthened, and reinforced, and each employee must be motivated and his/her efforts focused on the organization's goals and objectives" [103] (p. 127). Furthermore, Wong and Boh (2010) assert that in the knowledge economy, it is not the stock of human cap- 
ital that is important, but the extent to which it is combined and leveraged [105].

The main objective of this research is to identify the importance of retaining and managing the Intellectual Capital. In addition, it looks into both financial and non-financial benefits for employees. The study also focuses on the big impact of having a strong and effective Human Resources Department. The survey results have revealed that $93.41 \%$ of employees are not only looking for financial benefits, but also for non-financial benefits such as job security, healthy work environment, respect, worklife balance, etc... This coincides with Pfeffer's (2001) argument which states that paying people more is seldom the most important factor in attracting and retaining $\mathrm{Hu}$ man Capital [106]. Therefore, in order to find more ways to retain the Intellectual Capital, a question was posted on Researchgate.net (2016, a social networking site for scientists and researchers) to know what non-financial factors will retain the Human Capital at the company. The question was: "Other than good 'Financial Benefits', what makes an employee stay with the company he/she works at?" The question was shared with all the researchers on the site, and Exhibit 2 depicts some of the answers.

Exhibit 2. Responses collected from Resaerchgate.net.

- Feeling the nurturing culture where support, empathy, and career plan exist.

- Could be the feeling of belonging to a successful team and being active part of it.

- An interesting job, great colleagues, reasonable bosses, a manageable workload, good career perspectives...

- The more reputable the company, the longer duration and more employees stick to the company. Some of the young employees try to learn as much as they can before exploring out for better job opportunity.

- Apart from salary, employees stay with the organizations because of working atmosphere/colleagues, Job Content, Career Opportunities, Training, Company Image, Company Culture, The Management, Internal Opportunities. Again apart from the aforementioned factors, the most important factor is the role of a supervisor or being fortunate to get a good boss because problems with the boss is the main reason why employees do not like to stay. Employee satisfaction and commitment factors are under the control of the managers, supervisors or team leaders (A Survey done by Hay Group, 1998, the sample size was half million employees over 300 companies).

- Job Satisfaction, Superior's Treatment, Participatory Culture, and Due Recognition.

- Some of these factors are job security, good working conditions, loyalty, full appreciation of work, specific type of job, etc.

- An interesting environment, kind and great colleagues and bosses, a manageable workload, and respect (among colleagues and also customers).

- In some places or countries, it is hard to have opportunities to change for better job's conditions and salary. People stay in the same company for their salary and the number or years of personal investment in their career despite the dissatisfaction and the frustration.

- When a person has a personal agenda for improvement within the current job, he/ 
she will stick to it until objectives are achieved. From there on, the different factors mentioned in this forum are weighted against the next planned move.

- Financial Benefits are used more to attract new people to join the company (although it will increase the level of satisfaction and employee retention). Job Security, Clear Code of Business Conducts, and a management that "LISTENS" and "ACTS" are some factors that will retain the employee within the organization.

- "Bad Bosses" cause high turnover of employees. The problem grows further by the bosses not realizing that what they are doing is wrong.

- The scheme of succession planning.

The collected responses shown in Exhibit 2 are but a few of what researchers and scientists have to say. Mach (2015, May 19), in her article titled, "Leadership according to Inc. Magazine's Top 5: Jack Welch", refers to Jack Welch's famous quote regarding compensation: "If you pick the right people and give them the opportunity to spread their wings and put compensation as a carrier behind it, you almost don't have to manage them" [107] (Para 2). So, it is about giving the opportunities!

This research has attempted to shed light on and explore current Lebanese "Intellectual Capital" practices as a modern HR concept that has influenced business processes and plans. Overall, findings provide support and evidence to the fact that Lebanese employers and employees bring forward a fair and positive feedback to the study and managers take the process seriously despite the fact that only $49.22 \%$ of the surveyed employees will stay at the company because of the Non-financial Benefits whatever the Financial Benefits are, and $56.2 \%$ of the employees surveyed are satisfied with the company's financial benefits.

According to Andrews (2009), the Intellectual Capital component is not well understood [99]. The key challenge in Intellectual Capital Management is transforming intangible assets into something that creates value for the organization. Organizations of the $21^{\text {st }}$ century need to have dynamic capability, that is, the ability to achieve new forms of competitive advantage by appropriately adapting, integrating, and reconfiguring intangible assets (organizational skills, resources, and competencies). Understanding intangible assets provides new strategic insights and competitive options for supply chain design and operation. The resultant model of the current research confirms what Andrews (2009) recommends when assuring that organizational sustained efforts to keep active work environment, clarity of responsibilities and duties, and a positive way of communication will promote organizational readiness to implement retention planning frameworks [99]. Furthermore, and according to Hejase, Eid, Hamdar, and Haddad (2012a), "many Lebanese companies failed to identify their employees' talents; they should start considering anyone working for their company as a talent and should invest in it" [108] (p. 31).

Sharabati, Jawad, \& Bontis (2010) contend that the "concept of intellectual capital is a newly emerging concept, and until now, it is not fully understood by most organizations in Jordan or the Arab world" [109] (p. 117). Therefore, and as Hejase, Rifai, Tabsh, and Hejase (2012b) contend, "it is urgently recommended that strategically integrated human capital programs like talent management are to be adopted to capitalize 
on the new generation of better prepared future employees" [110] (p. 37).

This paper contributes to the ongoing research on the topic within the Arab region ([111]-[113]), whereby results and findings add to the fact that Middle Eastern countries are undergoing the transformation from considering tangible assets as primary to considering human capital as the asset for the future. Bontis (2002) asserts that "the Arab region has long been known for its rich natural resources. The oil industry is recognized as the key component of national income for this region. However, the intellectual capital of this region is the renewable asset of this developing territory and must become a top priority for each constituent in order to sustain an increased financial well-being" [114] (p. 19). Moreover, Seleim et al. (2007) contends that there is a relationship between Human Capital and business performance in Egyptian software companies [113]. Moreover, Safieddine, Jamali, and Noureddine (2009) assert in their case study in Lebanon the relationship between Intellectual Capital (IC) and Corporate Governance (CG) [115], (The OECD (Organization for Economic Cooperation and Development)) (2004) introduces corporate governance as "one key element in improving economic efficiency and growth as well as enhancing investor confidence. Corporate governance involves a set of relationships between a company's management, its board, its shareholders and other stakeholders" [116] (p. 11)), in an academic setting; based on the responses of faculty members of the American University of Beirut (AUB), CG and IC are indeed interrelated, and that IC is the latent force that enhances an organization's ability to attract more IC. Moreover, Sharabati et al. (2010) in their research about pharmaceutical companies in Jordan have confirmed the relationship between IC and business performance [109].

Furthermore, Serenko et al. (2007, cited in Sharabati et al., 2010, p. 117) suggests that "it is important for the Jordanian government to harvest the full potential of its people by investing in appropriate technological infrastructure so that human capital can be converted (or processed) into increased wealth and a higher standard of living. This can be achieved for organizations regardless of size" [109].

Finally, within the aim of the current paper to explore and assess the current challenges IC faces, and to offer insights into its future, the following recommendations are offered for all companies:

- Focus on the importance of Human Resources Management inside the company.

- Share the awareness of the company's policies and operational procedures.

- Make sure that all employees are aware of the company's culture and mission.

- Select talented employees with outgoing personalities and who are teamwork oriented.

- Increase the efficiency of training and development.

- Increase the level of employee's involvement and empowerment.

- Look for new ways to improve the level of Knowledge Management through different programs and activities.

- Consider Human Capital as the number one competitive advantage against other companies.

- Implement new methods and ways to retain the Human Capital at the company as it 
is a major asset and a secret behind the success.

\subsection{Limitations}

The concept of Intellectual Capital is becoming popular with time; however, the number of studies conducted around this concept in Lebanon is very small. Although the sample size of the survey consists of 258 respondents, this number is just enough to explore the topic in question but results and findings may not be generalized because the respondents do not represent all the economic sectors of Lebanon.

\subsection{Future Research}

Several points must be taken into consideration once future related researches are conducted:

Researchers may focus on specific economic sectors to be able to conduct comparative analysis; researchers from the Arab countries may duplicate the research to upgrade the published results pertaining to other studies, which are very few; future researchers can focus on one type of benefits-either the financial or non-financial-so that the impacts of the benefits are well-analyzed; and, future researches may include analysis on how to let valuable employees adapt to the culture and live the values of the organization.

\section{Acknowledgements}

The authors would like to acknowledge the valuable constructive criticism and editing performed by Mrs. Henriette Skaff, senior editor at American University of Science and Technology's Publications Department.

\section{References}

[1] Huang, C.J. and Liu, C.J. (2005) Exploration for the Relationship between Innovation, IT and Performance. Journal of Intellectual Capital, 6, 237-252. http://dx.doi.org/10.1108/14691930510592825

[2] Hejase, H.J., Hejase, A.J., Mikdashi, G. and Farhat, Z. (2016) Talent Management Challenges: An Exploratory Assessment from Lebanon. International Journal of Business Management and Economic Research, 7, 504-520.

[3] Rappaport, A. (2006) Ten Ways to Create Shareholder Value. Harvard Business Review. https://hbr.org/2006/09/ten-ways-to-create-shareholder-value

[4] Robbins, S.P. and Coulter, M.K. (2009) Management. 10th Edition, Pearson Education, Inc., Upper Saddle River.

[5] Lockwood, N. (2006) Talent Management: Driver for Organizational Success. SHRM Research Report Quarterly. https://www.shrm.org/Research/Articles/Articles/Documents/0606RQuartpdf.pdf

[6] Mondy, R.W. and Mondy, J.B. (2012) Human Resource Management.12th Edition, Pearson Education Limited, Boston.

[7] Berger, B. (2008) Employee/Organizational Communications. http://www.instituteforpr.org/employee-organizational-communications/ 
[8] Jayaraman, R. (2012) Succeeding through People: An Overview of How Business Excellence Practices Have Changed the HR Landscape. Advances in Management, 5, 14-20.

http://dx.doi.org/10.17010//2013/v6i1/59944

[9] Conner, J. and Ulrich, D. (1996) Human Resource Roles: Creating Value, Not Rhetoric. Human Resource Planning, 19, 38-49.

[10] Lawler III, E.E. (2011) Celebrating 50 Years: HR: Time for a Reset? Human Resource Management, 50, 171-173. http://dx.doi.org/10.1002/hrm.20420

[11] Lawler III, E., Ulrich, D., Fitz-Enz, J., Madden, V. and James, C. (2004) Human Resources Business Process Outsourcing: Transforming how HR Gets Its Work Done. Jossey-Bass/ Wiley Imprint, San Francisco.

[12] Adelman, S. (2010) Intellectual Capital: A Human Resources Perspective. http://www.eiminstitute.org/current-magazine/volumn-4-issue-5-october-2010/intellectualcapital-a-human-resources-perspective

[13] Jurczak, J. (2008) Intellectual Capital Measurement Methods. http://www.orgmasz.pl/wydawnictwo/files/Intellectual.pdf http://dx.doi.org/10.2478/v10061-008-0005-y

[14] Kavida, V. and Sivakoumar, N. (2008) Corporate Governance in Knowledge EconomyThe Relevance of Intellectual Capital. http://ssrn.com/abstract=1152892 http://dx.doi.org/10.2139/ssrn.1152892

[15] Atashi, A. and Kharabi, H. (2012) Intellectual Capital Management, a Paradigm to Enhance the Human Resource Management in Knowledge-Based Economy. Life Science Journal, 9, 1336-1340.

[16] Kozak, M. (2011) Strategic Approach to Intellectual Capital Development in Regions. International Journal of Learning and Intellectual Capital, 8, 76-93. http://dx.doi.org/10.1504/IJLIC.2011.037360.

[17] Khan, M.W.J. (2014) Identifying the Components and Importance of Intellectual Capital in Knowledge-Intensive Organizations. Business and Economic Research, 4, 297-307. http://dx.doi.org/10.5296/ber.v4i2.6594

[18] Bontis, N. (1998) Intellectual Capital; an Exploratory Study That Develops Measures and Models. Management Decision, 36, 63-76. http://dx.doi.org/10.1108/00251749810204142

[19] Edvinsson, L. and Sullivan, P. (1996) Developing a Model for Managing Intellectual Capital. European Management Journal, 14, 356-364. http://dx.doi.org/10.1016/0263-2373(96)00022-9

[20] Stewart, T.A. (1997) Intellectual Capital: The New Wealth of Organizations. Doubleday/Currency, New York.

[21] Young, J. (2012) Personal Knowledge Capital: The Inner and Outer Path of Knowledge Creation. Chandos Publishing, Oxford. http://dx.doi.org/10.1533/9781780633664

[22] Lev, B. (2001) Intangibles: Management, Measurement, and Reporting. Brookings Institution Press, Washington DC, 113-122.

[23] Edvinsson, L. (1997) Developing Intellectual Capital at Skandia. Long Range Planning, 20, 366-373. http://dx.doi.org/10.1016/S0024-6301(97)90248-X

[24] Harrison, S. and Sullivan, P.H. (2000) Profiting from Intellectual Capital. Learning from Leading Companies. Journal of Intellectual Capital, 1, 36-44. http://dx.doi.org/10.1108/14691930010324124

[25] Kong, E. and Thomson, S.B. (2009) An Intellectual Capital Perspective of Human Resource Strategies and Practices. Knowledge Management Research \& Practice, 7, 356-364. http://dx.doi.org/10.1057/kmrp.2009.27 
[26] Abdullah, D.F. and Sofian, S. (2012) The Relationship between Intellectual Capital and Corporate Performance. Procedia-Social and Behavioral Sciences, 40, 537-541. http://dx.doi.org/10.1016/j.sbspro.2012.03.227

[27] Stralser, S. (2004) MBA in a Day: What You Would Learn at Top-Tier Business Schools (If You Only Had the Time!) (English Edition). John Wiley \& Sons, New York.

[28] Bontis, N. (1999) Managing Organizational Knowledge by Diagnosing Intellectual Capital: Framing and Advancing the State of the Field. International Journal of Technology Management, 18, 433-463. http://dx.doi.org/10.1504/IJTM.1999.002780

[29] Bontis, N., Chua, W.C.K. and Richardson, S. (2000) Intellectual Capital and Business Performance in Malaysian Industries. Journal of Intellectual Capital, 1, 85-100. http://dx.doi.org/10.1108/14691930010324188

[30] Andriessen, D. (2004) IC valuation and Measurement Classifying the State of the Art. Journal of Intellectual Capital, 5, 230-242. http://dx.doi.org/10.1108/14691930410533669

[31] Cohen, J.A. (2005) Intangible Assets, Valuation and Economic Benefit. John Wiley \& Sons. Hoboken.

[32] Blair, M. and Wallman, S. (2003) The Growing Intangibles Reporting Discrepancy, Intangibles: Management, Measurement, and Reporting. Brooking Institution Press, John Hand and Baruch Lev (Ed.), Washington DC, 449-468.

[33] Epstein, B.J. and Mirza, A.A. (2005) IPRS-Interpretation and Application of International Accounting and Financial Reporting Standards. John Wiley \& Sons, Hoboken.

[34] Carroll, R.F. and Tansey, R.R. (2000) Intellectual Capital in the New Internet Economy-Its Meaning, Measurement and Management for Enhancing Quality. Journal of Intellectual Capital, 1, 296-312. http://dx.doi.org/10.1108/14691930010359216

[35] Sullivan, Jr., P.H. and Sullivan, Sr., P.H. (2001) Valuing Intangibles Companies: An Intellectual Capital Approach. Journal of Intellectual Capital, 1, 328-340. http://dx.doi.org/10.1108/14691930010359234

[36] Seetharaman, A., Sooria, H.H.B.Z. and Saravanan, A.S. (2002) Intellectual Capital Accounting and Reporting in the Knowledge Economy. Journal of Intellectual Capital, 3, 128-148. http://dx.doi.org/10.1108/14691930210424734

[37] Rastogi, P.N. (2002) Knowledge Management and Intellectual Capital as a Paradigm of Value Creation. Human Systems Management, 21, 229-240.

[38] Mohtar, S., Safura, I. and Abbas, A.R.M. (2015) Intellectual Capital and Its Major Components. Journal of Technology and Operations Management, 10, 15-21.

[39] Sherman, A. (2002) Strategies for Managing \& Leveraging Intellectual Capital. http://www.tvworldwide.com/events/growfastgrowright/version10/presentations/Strategies For Managing Leveraging Intellectual Capital.pdf

[40] Qilichli, B. and Moshabbaki, A. (2006) The Role of Social Capital in Creating Intellectual Capital in Organization, Study on Two Automobile Co. Journal of Management Knowledge, 75, 125-147.

[41] Mitchell, H.J. (2010) A Model for Managing Intellectual Capital to Generate Wealth. Doctoral Thesis, Massey University Theses and Dissertations, Massey University, Albany. http://mro.massey.ac.nz/handle/10179/1369

[42] Pourkiani, M., Sheikhy, A. and Daroneh, M.S. (2014) Importance and Status of Intellectual Capital in Knowledge Economy. Indian Journal of Fundamental and Applied Life Sciences, 4, 512-518.

[43] Steel, R.P., Griffeth, R.W. and Hom, P. W. (2002) Practical Retention Policy for the Practical 
Manager. Academy of Management Executive, 18, 149-169. http://dx.doi.org/10.5465/AME.2002.7173588

[44] Frey, B. and Osterloh, M. (2002) Successful Management by Motivation: Balancing Intrinsic and Extrinsic Motivation. Springer, Berlin. http://dx.doi.org/10.1007/978-3-662-10132-2

[45] Montano, B. (2005) Innovations of Knowledge Management. IRM Press, Hershey.

[46] Akhavan, P., Jafari, M. and Fathian, M. (2005) Exploring Failure-Factors of Implementing Knowledge Management Systems in Organizations. Journal of Knowledge Management Practice, 6, 1-8.

[47] Hejase, H.J., Haddad, Z., Hamdar, B., Al, A., Rola, H., Ale, J. and Beyrouti, N. (2014) Knowledge Sharing: Assessment of Factors Affecting Employee' Motivation and Behavior in the Lebanese Organizations. Journal of Scientific Research \& Reports (JSRR), 3, 1549-1593. http://dx.doi.org/10.9734/JSRR/2014/8107

[48] Sveiby, K.E. (1997) The New Organizational Wealth: Managing and Measuring Knowledge Based Assets. Berett-Koehler Publisher, San Francisco.

[49] Edvinsson, L. and Malone, M. (1997) Intellectual Capital. Harper Business, New York.

[50] Bontis, N. (2000) Assessing Knowledge Assets: A Review of the Models Used To Measure Intellectual Capital.

http://citeseerx.ist.psu.edu/viewdoc/download?doi=10.1.1.112.8365\&rep=rep1\&type=pdf

[51] Ismail, M.B. (2005) The Influence of Intellectual Capital on the Performance of Telekom Malaysia. Phd Dissertation, Universiti Teknologi Malaysia, Skudai.

[52] Bueno, E., Salvador, M. and Rodriguez, O. (2004) The Role of Social Capital in Today's Economy Empirical Evidence and Proposal of a New Model of Intellectual Capital. Journal of Intellectual Capital, 5, 556-574. http://dx.doi.org/10.1108/14691930410567013

[53] Wu, W.-Y. and Tsai, H.-J. (2005) Impact of Social Capital and Business Operation Mode on Intellectual Capital and Knowledge Management. International Journal Technology Management, 30. http://dx.doi.org/10.1504/IJTM.2005.006353

[54] Ramezan, M. (2011) Intellectual Capital and Organizational Organic Structure in Knowledge Society: How Are These Concepts Related? International Journal of Information Management, 31, 88-95. http://dx.doi.org/10.1016/j.ijinfomgt.2010.10.004

[55] Nemec Rudež, H. (2005) Intellectual Capital-A Fundamental Change in Economy: A Case Based on Service Industries. Proceedings of the 5 th International Conference of the Faculty of Management Koper, Koper. University of Primorska Slovenia. http://www.fm-kp.si/zalozba/ISBN/961-6486-71-3/323-335.pdf

[56] Schultz, T.W. (1961) Investment in Human Capital. American Economic Review, 51, 1-17.

[57] Ordoñez, P. (2003) Intellectual Capital Reporting in Spain: a Comparative View. Journal of Intellectual Capital, 4, 61-81. http://dx.doi.org/10.1108/14691930310455397

[58] Lee, S., Phan, P. and Tan, G. (2003) Impact of the Asian Economic Crisis on Training Intensions and Outcome. Human Resource Management Review, 12, 467-486. http://dx.doi.org/10.1016/S1053-4822(03)00046-9

[59] Seleim, A., Ashour, A. and Bontis, N. (2004) Intellectual Capital in Egyptian Software Firms. The Learning Organization, 11, 332-346. http://dx.doi.org/10.1108/09696470410538233

[60] Starovic, D. and Marr, B. (2004) Understanding Corporate Value: Managing and Reporting Intellectual Capital. The Chartered Institute of Management Accountants (CIMA) and Cranfield University, London. http://www.cimaglobal.com/Documents/ImportedDocuments/intellectualcapital.pdf

[61] Bontis, N. and Serenko, A. (2009)A Causal Model of Human Capital Antecedents and Con- 
sequents in the Financial Services Industry. Journal of Intellectual Capital, 10, 53-69. http://dx.doi.org/10.1108/14691930910922897

[62] Mousavi, Z., Moeinfar, Z. and Amouzesh, N. (2013) The Role of Intellectual Capital in Knowledge-Based Economy. http://www.lifesciencesite.com/lsj/life1006s/010 17591life1006s 56 60.pdf

[63] Jamshidy, M., Sofian, S., Bajuri, N.H. and Karchegani, M.R. (2014) Influence of Intellectual Capital on the Board of Directors' Styles. Asian Journal of Applied Sciences, 7, 51-65. http://scialert.net/abstract/?doi=ajaps.2014.51.65 http://dx.doi.org/10.3923/ajaps.2014.51.65

[64] Fragouli, E. (2010) Intellectual Capital and Organizational Advantage: An Economic Approach to Its Valuation and Measurement. Proceedings of the $9 \mathrm{t} h$ Annual Meeting of the EEFS International Conference, Athens, 3-6 June 2010, 1-22.

[65] Roos, G., Bainbridge, A. and Jacobsen, K.K. (2001) Intellectual Capital Analysis as a Strategic Tool. Strategy Leadership, 29, 21-28. http://dx.doi.org/10.1108/10878570110400116

[66] Ciemleja, G. and Lāce, N. (2008) The Role of Customer Capital for SME Sustainable Development. International Scientific Conference "Customer Relationship Management '08 (CRM 2008): Proceedings of the Papers, Pardubice, 24-25 September 2008, 30-37.

[67] Yang, T.-N., Chang, H.-C., Lin, S.-Y. and Tsao, C.-L. (2011) Knowledge Creation and Intellectual Capital on Securities Investment Services. African Journal of Business Management, 5, 924-933.

[68] Monks, R.A.G. and Minow, N. (2008) Corporate Governance. 4th Edition, John Wiley and Sons Ltd., Chichester.

[69] Middlebrooks, A. and Noghiu, A. (2010) Leadership and Spiritual Capital: Exploring the Link between Individual Service Disposition and Organizational Value. International Journal of Leadership Studies, 6, 67-85.

[70] Requena, F. (2002) Social Capital in the Spanish Quality of Working Life Survey. OECD-UK ONS International Conference on Social Capital Measurement, London, 25-27 September 2002, 1-16. http://www.oecd.org/spain/2382039.pdf

[71] Çelik, V. and Ekinci, A. (2012) The Effects of Social Capital on School Success. International Journal of Social Sciences and Education, 2, 211-223.

[72] De Castro, G.M., Navas López, J.E., García Muiñac, F.E. and Sáez, P.L. (2004) A New Model to Measure and manage Intellectual Capital. http://www2.warwick.ac.uk/fac/soc/wbs/conf/olkc/archive/oklc5/papers/k-4 decastro.pdf

[73] Longo-Somoza, M., Bueno, E. and Acosta-Prado, J.C. (2015) Social Processes of Knowledge of Technological Capabilities and Intellectual Capital on New Technology-Based Firms. Global Journal of Management and Business Research: G Interdisciplinary, 15, 1-18.

[74] Marr, B. (2008) Impacting Future Value: How to Manage your Intellectual Capital. Management Accounting Guideline (MAG) Jointly Published by CMA, AICPA, and CIMA. http://www.journalofaccountancy.com/content/dam/jofa/archive/issues/2008/09/mag-intca pital-eng.pdf

[75] Talukdar, A. (2008) What Is Intellectual Capital? And Why It Should Be Measured. http://www.attainix.com/Downloads/WhatIsIntellectualCapital.pdf

[76] Müller, C. (2004) The 3 Ms of Intellectual Capital-Measuring, Monitoring and Managing. The 5th European Conference on Organizational Knowledge, Learning, and Capabilities, Session K-2, University of Innsbruck, Innsbuck, 2-3 April 2004, 1-18. http://www2.warwick.ac.uk/fac/soc/wbs/conf/olkc/archive/oklc5/papers/k-2 mueller.pdf

[77] Neely, A., Marr, B., Roos, G., Pike, S. and Gupta, O. (2003) Towards the Third Generation 
of Performance Measurement. Controlling, 3/4, 129-135.

http://dx.doi.org/10.15358/0935-0381-2003-3-4-129

[78] Sitar, A.S. and Vasic, V. (2004) Measuring Intellectual Capital: Lessons Learned from a Practical Implementation. http://www.fm-kp.si/zalozba/ISBN/961-6486-71-3/337-351.pdf

[79] Sveiby, K.-E. (2010) Methods for Measuring Intangible Assets. http://www.sveiby.com/articles/IntangibleMethods.htm

[80] Gogan, M.L. (2014) Analysis of the Models for Measuring Intellectual Capital. Annals of the Oradea University Fascicle of Management and Technological Engineering, Issue 1, 175179. http://dx.doi.org/10.15660/auofmte.2014-1.2979

[81] Nahapiet, J. and Ghoshal, S. (1998) Social Capital, Intellectual Capital and the Organizational Advantage, Academy of Management. The Academy of Management Review, 3, 242266. http://staffweb.hkbu.edu.hk/vwschow/lectures/ism3620/rp01.pdf

[82] Ling. Y.H. (2012) A Study on the Influence of Intellectual Capital and Intellectual Capital Complementarity on Global Initiatives. The Electronic Journal of Knowledge Management, 10, 154-162.

[83] Khalique, M., Shaari, J.A.N. and Isa, A.H.B.M. (2011, June) Intellectual Capital and Its Major Components. International Journal of Current Research, 3, 343-347.

[84] Ling, Y.H. (2011) The Influence of Intellectual Capital on Organizational PerformanceKnowledge Management as Moderator. Asia Pacific Journal of Management, 30, 937-964. http://dx.doi.org/10.1007/s10490-011-9257-5

[85] Hermans, R. and Kauranen, I. (2005) Value Creation Potential of Intellectual Capital in Biotechnology_Empirical Evidence from Finland. R\&D Management, 35, 171-185. http://dx.doi.org/10.1111/j.1467-9310.2005.00381.x

[86] Subramaniam, M. and Youndt, M.A. (2005) The Influence of Intellectual Capital on the Types of Innovative Capabilities. Academy of Management Journal, 48, 450-463. http://dx.doi.org/10.5465/AMJ.2005.17407911

[87] Tsen, S. H. and Hu, H.L. (2010) A Research on the Organizational Competitiveness and the Indicators of the Intellectual Capital: In the Case on the International Tourist Hotels. Journal of Human Resource Management, 10, 79-104.

[88] Gloet, M. and Terziovski, M. (2004) Exploring the Relationship between Knowledge Management Practices and Innovation Performance. Journal of Manufacturing Technology Management, 15, 402-409. http://dx.doi.org/10.1108/17410380410540390

[89] Seleim, .A.S. and Khalil, O.E.M. (2011) Understanding the Knowledge Management-Intellectual Capital Relationship: A Two-Way Analysis. Journal of Intellectual Capital, 12, 586614. http://dx.doi.org/10.1108/14691931111181742

[90] Hsu, I.C. and Sabherwal, R. (2012) Relationship between Intellectual Capital and Knowledge Management: An Empirical Investigation. Decision Sciences, 43, 489-524. http://dx.doi.org/10.1111/j.1540-5915.2012.00357.x

[91] Kör, B. and Maden, C. (2013) The Relationship between Knowledge Management and Innovation in Turkish Service and High-Tech Firms. International Journal of Business and Social Science, 4, 293-304.

[92] Guthrie, J., Petty, R. and Ricceri, F. (2006) The Voluntary Reporting of Intellectual Capital: Comparing Evidence from Hong Kong and Australia. Journal of Intellectual Capital, 7, 254271. http://dx.doi.org/10.1108/14691930610661890

[93] Rexhepi, G., Ibraimi, S. and Veseli, N. (2013) Role of Intellectual Capital in Creating Enterprise Strategy. Procedia-Social and Behavioral Sciences, 75, 44-51.

http://dx.doi.org/10.1016/j.sbspro.2013.04.006 
[94] Harrison, S. and Sullivan, H.P. (2002) Profiting from Intellectual Capital: Learning from Leading Companies. Industrial and Commercial Training, 32, 139-148. http://dx.doi.org/10.1108/00197850010372232

[95] Hamzah, N. and Ismail, M.N. (2008) The Importance of Intellectual Capital Management in the Knowledge-Based Economy. Contemporary Management Research, 4, 237-262. http://dx.doi.org/10.7903/cmr.1045

[96] Laing, G., Dunn, J. and Lucas, S.H. (2010) Applying the VAIC model to Australian Hotels. Journal of Intellectual Capital, 11, 269-283. http://dx.doi.org/10.1108/14691931011064545

[97] Ul-Rehman, W., Asghar, N. and Ur Rehman, H. (2013) Intellectual Capital Efficiency and Financial Performance of Insurance Sector in Pakistan: A Panel Data Analysis. Middle-East Journal of Scientific Research, 17, 1251-1259.

[98] Roos, G., Pike, S. and Fernström, L. (2006) Managing Intellectual Capital in Practice. Butterworth-Heinemann, New York, 19.

[99] Andrews, K. (2009) The Importance of Intellectual Capital and Knowledge in the Design and Operation of Enterprise Supply Chains. http://www.knowable.com.au/documents/pdfs/article 7-intellectual capital.pdf

[100] Lynn, B. (2000) Intellectual Capital: Unearthing hidden Value by Managing Intellectual Assets. Ivey Business Journal, 64, 48-52.

[101] Hejase, A.J. and Hejase, H.J. (2013) Research Methods: A Practical Approach for Business Students. 2nd Edition, Masadir Inc., Philadelphia.

[102] Wyse, S. (2012) Benefits of Using Cross Tabulations in Survey Analysis. http://www.snapsurveys.com/blog/benefits-cross-tabulations-survey-analysis/

[103] Dess, G.G., Lumpkin, G.T. and Eisner, A.B. (2008) Strategic Management: Text and Cases. 4th Edition, McGraw-Hill/Irwin, Boston.

[104] Dess, G.G. and Lumpkin, G.T. (2001) Emerging Issues in Strategy Process Research. In: Hitt, M.A., Freeman, R.E. and Harrison, J.S., Eds., Handbook of Strategic Management, Blackwell, Malden, 3-34.

[105] Wong, S.S. and Boh, W.F. (2010) Leveraging the Ties of Others to Build a Reputation for Trustworthiness among Peers. Academy of Management Journal, 53, 129-148. http://dx.doi.org/10.5465/AMJ.2010.48037265

[106] Pfeffer, J. (2001) Fighting the War for Talent Is Hazardous to Your Organization's Health. Organizational Dynamics, 29, 248-259. http://dx.doi.org/10.1016/S0090-2616(01)00031-6

[107] Mach, K. (2015) Leadership According to Inc. Magazine’s Top 5: Jack Welch. http://www.talentplus.com/talent-plus-viewpoint-blog/35-leadership/646-leadership-accor ding-to-inc-magazine-s-top-5-jack-welch

[108] Hejase, H.J., Eid, A., Hamdar, B. and Haddad, Z. (2012) Talent Management: An Assessment of Lebanese Employees' Knowledge. Universal Journal of Management and Social Sciences, 2, 21-38. http://dx.doi.org/10.1108/00251741011014481

[109] Sharabati, A.A., Jawad, S.N. and Bontis, N. (2010) Intellectual Capital and Business Performance in the Pharmaceutical Sector of Jordan. Management Decision, 48, 105-131. http://dx.doi.org/10.1108/00251741011014481

[110] Hejase, H.J., Rifai, R., Tabsh, H. and Hejase, A.J. (2012) Major Forces Leading to the Shift in the HR Function in Lebanon: An Exploratory Research. British Journal of Humanities and Social Sciences, 7, 21-39.

[111] Bontis, N. (2003) National Intellectual Capital Index: The Benchmarking of Arab Countries. United Nations Development Project, New York. 
[112] Bontis, N. (2004) National Intellectual Capital Index: a United Nations initiative for the Arab Region. Journal of Intellectual Capital, 5, 13-39. http://dx.doi.org/10.1108/14691930410512905

[113] Seleim, A., Ashour, A. and Bontis, N. (2007) Human Capital and Organizational Performance: A Study of Egyptian Software Companies. Managing Decision, 45, 789-901. http://dx.doi.org/10.1108/00251740710746033

[114] Bontis, N. (2002) National Intellectual Capital Index: The Benchmarking of Arab Countries.

http://citeseerx.ist.psu.edu/viewdoc/download?doi=10.1.1.471.7175\&rep=rep1\&type=pdf

[115] Safieddine, A., Jamali, D. and Noureddine, S. (2009) Corporate Governance and Intellectual Capital: Evidence from an Academic Institution. Corporate Governance, 9, 146-157. http://dx.doi.org/10.1108/14720700910946596

[116] Organization for Economic Cooperation and Development (OECD) (2004) OECD Principles of Corporate Governance. https://www.oecd.org/corporate/ca/corporategovernanceprinciples/31557724.pdf

\section{Submit or recommend next manuscript to SCIRP and we will provide best service} for you:

Accepting pre-submission inquiries through Email, Facebook, LinkedIn, Twitter, etc. A wide selection of journals (inclusive of 9 subjects, more than 200 journals)

Providing 24-hour high-quality service

User-friendly online submission system

Fair and swift peer-review system

Efficient typesetting and proofreading procedure

Display of the result of downloads and visits, as well as the number of cited articles

Maximum dissemination of your research work

Submit your manuscript at: http://papersubmission.scirp.org/ 